\title{
ROHINGYAS AND THE (IL)LEGAL QUEST FOR AN INDIAN IDENTITY
}

\author{
TEJAL KHANNA*
}

TABLE OF CONTENTS

I Introduction

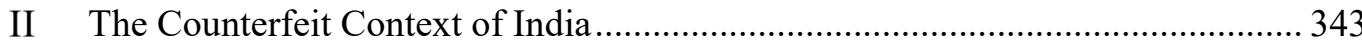

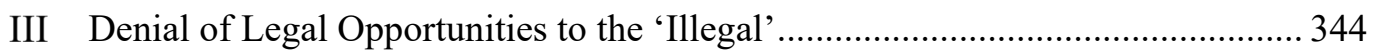

IV Treating Root Causes to Stop the Stateless from Committing Crimes ................. 346

\section{INTRODUCTION}

The arrests of Rohingyas who have tried to obtain Indian identity documents, like the Aadhaar card, ${ }^{1}$ has been on the rise. Across several states of India, and particularly in the city of Hyderabad, Rohingyas have been held by police under allegations that they are in possession of fake Aadhaar cards. ${ }^{2}$ Apart from the Aadhaar card, there have also been reported cases of the community acquiring other Indian documents such as the PAN Card, ${ }^{3}$ Voter ID card and even the Indian passport. Just last year, in May 2019, Mohammed Faisal, a young Rohingya, was arrested at Delhi's Indira Gandhi International airport for posing as an Indian national with a fake passport in an attempt to travel to Indonesia. ${ }^{4}$ It was later revealed during an investigation that he was able to acquire the Indian passport through his contacts in Hyderabad while his asylum application to the United Nations High Commissioner for Refugees ('UNHCR') was still under consideration. Similar cases continue to occur even in times of the COVID-19 public health emergency. For example, in June 2020, in the southern state of Telangana, five Rohingyas, including three women, were arrested for illegal

* Tejal Khanna is a doctoral candidate at the Centre for International Politics, Organisation and Disarmament, School of International Studies, Jawaharlal Nehru University, India. Currently, she is also interning with Rohingya Human Rights Initiative, a non-governmental organisation based in New Delhi. Previously, she has also participated in the Statelessness Intensive Course organised by the Peter McMullin Centre on Statelessness, Melbourne Law School, University of Melbourne in February 2020. The author is deeply grateful to the peer reviewers who provided extensive and valuable feedback for this commentary.

1 The Aadhaar card provides a proof of identity (but not of citizenship) to an individual, irrespective of age and gender, who is a resident of India. The Aadhaar number is a unique 12-digit random number that is generated after an individual, voluntary, provides their demographic and biometric data. For more on Aadhaar, see 'Unique Identity Authority of India', Government of India (Web Page) < https://uidai.gov.in/>.

2 'Hyderabad: 3 Rohingya Muslims with Aadhaar, ID Cards Held', Times of India (online, 5 July 2018) <https://timesofindia.indiatimes.com/city/hyderabad/hyderabad-3-rohingyaswith-aadhaar-id-cards-held/articleshow/64870909.cms $>$.

3 'PAN' in PAN Card refers to Permanent Account Number - a unique alpha-numeric number. Apart from acting as proof of identity, the PAN card is essential for conducting certain financial transactions, such as filing income tax-returns in India.

4 'Rohingya Man Arrested at Delhi Airport with Fake Indian Passport', Hindustan Times (online, 19 May 2019) <https://www.hindustantimes.com/delhi-news/rohingya-manarrested-at-delhi-airport-with-fake-indian-passport/storyN7xLRXAJK8ckDcStTz0gYK.html>. 
immigration when they procured Aadhaar cards and Indian passports through the provision of false information. ${ }^{5}$

Prima facie, there seems nothing wrong with these arrests; these are acts of forgery, cheating and giving false declaration - all of which violate Indian laws, particularly the Indian Penal Code and the Indian Passports Act. ${ }^{6}$ However, it is important to note the overall context within which these crimes have been committed. Two entities are prominent in this context. On the one hand are the Rohingyas, one of the world's most persecuted stateless minorities, who have been arbitrarily denied nationality by Myanmar and are without the citizenship of any country. On the other hand, is India, the world's largest democracy, which has held a good reputation for being a host to refugees for several years.

This commentary does not justify crime in any way. Rather, by examining the case of Rohingyas committing crimes against Indian laws, it seeks to draw attention to responsibility on the part of sovereign states when stateless persons that is, persons without the citizenship of any country - commit crimes against sovereign laws.

\section{The COUNTERfeit CONTEXT OF INDIA}

It is a grim reality that any identity card in India can be easily made through fraudulent means. The Aadhaar card aimed to curb this by giving a unique 12-digit number to every resident of India, capturing their biometric and demographic data. Unfortunately, fake Aadhaar cards are still in operation and are used not just by the Rohingyas, but by several non-citizens living within India. In fact, I can testify to this with my own experience. A couple of years ago I wanted to open a new bank account and one of the primary conditions was to provide Aadhaar card details. I still remember that I had to give my thumbprints several times before the reading machine could verify the authenticity of my Aadhaar card. At one point, the cashier even doubted me and declared, 'ma'am, you have a fake Aadhaar card!'

In India, the 'counterfeit' quickly follows the 'real' until it comes to a point that one needs sharp eyes to separate the two. Consider this, almost all official Indian government websites open with a disclaimer window alerting the user to fake websites in operation. The official website of the Ministry of External Affairs, which issues Indian passports, is not immune to this. Currently, the disclaimer window on the official website shows more than six fake websites that offer services to procure an Indian passport. ${ }^{7}$

Kamal Sadiq, in his book Paper Citizens, recognised the weak citizenshipidentification and documentation systems of developing countries like India. ${ }^{8} \mathrm{He}$ argued that illegal immigrants can easily acquire identity cards, like the ration card, and go on to become Indian citizens, a process he terms 'documentary citizenship'. ${ }^{9}$ In this respect, the Rohingyas who have tried to acquire identity documents, especially the Voter ID card and the Indian passport, can be seen as

5 '5 Rohingyas, Including 3 Women, Arrested for Illegal Immigration in Telangana', Ani News (online, 9 June 2020) <https://www.aninews.in/news/national/general-news/5-rohingyasincluding-3-women-arrested-for-illegal-immigration-in-telangana20200609205816/>.

6 See Indian Penal Code, Act No 45 of 1860 (India); Passports Act, Act No 15 of 1967 (India).

7 See Ministry of External Affairs (Web Page) $<$ mea.gov.in $>$.

8 Kamal Sadiq, Paper Citizens: How Illegal Immigrants Acquire Citizenship in Developing Countries (Oxford University Press 2009) 102-11. 
indulging in 'documentary citizenship'. However, the proportion of the Rohingya population opting for this 'documentary citizenship' is small compared to the total population of Rohingyas living in India. ${ }^{10}$

Rohingyas who acquire Aadhaar cards present a rather complex issue with no easy solution. While being in possession of a fake Aadhaar card is illegal, the larger question to be asked is, are Rohingyas residing in India eligible for the Aadhaar card? As per the criteria laid out for obtaining the Aadhaar card, a resident is defined as a person living in India 'for a period or periods amounting in all to one hundred and eighty-two days or more in the twelve months immediately preceding the date of application for enrolment'. ${ }^{11}$ Consequently, all Rohingyas living in India who have fulfilled the requirements of this residency period should be eligible for the Aadhaar card. However, this seems a distant reality, as Rohingyas are now being categorised as 'illegal immigrants' by the government. ${ }^{12}$

\section{Denial of Legal Opportunities to THE 'IlLEGAL'}

In 2018, in the lower house of the Indian parliament, the Union Minister of State for Home, Kiren Rijiju, stated that Rohingyas living in India do not enjoy the status of refugees and are 'illegal immigrants' involved in various illegal acts. ${ }^{13}$ In the same year, India deported seven Rohingyas from the detention centre in Assam to Myanmar, attracting criticism from the United Nations. ${ }^{14}$ The deportations, however, continued when another Rohingya family of five was deported in 2019. ${ }^{15}$ The government's actions have also been criticised from within the country. Indian lawyers have challenged the deportation of Rohingya on the basis that forcing them to return to Myanmar, where they face a threat to their life,

10 According to the United Nations High Commissioner for Refugees estimates, there are 18,000 registered Rohingya refugees living in India. In addition, the Indian government gives a figure of 40,000 Rohingyas living in India illegally. Still, a study undertaken by Manirban Calcutta Research Group of 2015 claimed that if non-enumerated refugees and asylum seekers were taken into account, the Rohingya population in India could be around 100,000. Compared to all these three figures of total Rohingya population, the number of Rohingyas procuring Indian identity documents fraudulently is small. See NHRC Notice to the Union Home Ministry over Report Move to Deport Rohingya Immigrants to Their Native Country (Press Release, National Human Rights Commission, India 18 August 2017); UNHCR Seeking Clarification from India over Return of Rohingya (Press Release, UNHCR 4 January 2019); Rohingyas: The Emergence of a Stateless Community (Report, Calcutta Research Group 2015).

11 The Aadhaar (Targeted Delivery of Financial and Other Subsidies, Benefits and Services) Act, 2016, Law No 18 of 2016 (India) art 2(v).

12 See, eg, Advisory No 24013/29/Misc./2017-CSR.III(i): Identification of Illegal Migrants and Monitoring Thereof (Letter, Ministry of Home Affairs 8 August 2017) $<$ https://www.mha.gov.in/sites/default/files/advisoryonillegalmigrant_10092017.PDF> ('Advisory No 24013/29/Misc./2017-CSR.III(i)').

13 'Not Refugees, Rohingya Involved in Illegal Acts: Kiren Rijiju', Indian Express (online, 1 August 2018) <https://indianexpress.com/article/india/not-refugees-rohingya-involved-inillegal-acts-kiren-rijiju-5285388/>.

14 'India under Fire as it Deports Rohingya Muslims to Myanmar', BBC News (online, 4 October 2018) <https://www.bbc.com/news/world-asia-india-45743951>.

15 'India Deports Second Rohingya Group to Myanmar, More Expulsions Likely', Reuters (online, 3 January 2019) <https://www.reuters.com/article/us-myanmar-rohingya-indiaidUSKCN1OX0FE>. 
violates art 21 of the Constitution of India 1950, which protects the fundamental right to life of all persons (extending to Rohingyas) and not just Indian citizens. ${ }^{16}$

This government crackdown has not only instilled a fear of deportation amongst the Rohingya community, but has also pushed them into the corner by denying them virtually all other avenues for obtaining any form of identity document. Calling Rohingyas 'illegal immigrants' not only meant their impending deportation, but also the subsequent denial of all other forms of identity including refugee status. The UNHCR issued refugee card can no longer provide security against non-refoulement to the Rohingyas living in India, and the government has arbitrarily discontinued the practice of giving Long Term Visas ('LTVs') to Rohingyas. ${ }^{17}$ A Rohingya living in India for many years shared his agony in the following way to me:

I had acquired the Aadhaar card (before 2018) through proper legal channels by providing my electricity bill and LTV. Suddenly, why is it that the Indian authorities have now cancelled my Aadhaar card? Even the refugee card issued by UNHCR to me is not being recognised. I have been staying in India certainly for more than one hundred and eighty two days. Even my children were born on Indian soil! When will I qualify to be an Indian resident? I do not want Indian citizenship. Rather, I dream of going back to Myanmar with full citizenship rights. I am thankful to the people of India for giving me shelter here... But I do not want to live in fear of deportation and suffer mental harassment like this every day. ${ }^{18}$

Rohingyas, on account of their religious identity as Muslims, have also been alleged to have 'terrorist links' to the Islamic state and are consequently seen as a 'security threat' to India, though there is no evidence to prove the same. ${ }^{19}$ Rohingyas, therefore, continue to be seen as Muslims who must be under continuous surveillance. Already, the police of the northern state of Jammu and Kashmir have started collecting personal data and biometrics of the Rohingyas living in the state. ${ }^{20}$

A new angle has now been added to the religious identity of Rohingyas. In July 2020, reports claimed that Rohingya Muslims along with Afghan Muslims were converting to Christianity to claim citizenship status under the Citizenship

16 'Deporting Rohingya Could Have Huge Implications on India and Tarnish Global Image, Says Lawyer Colin Gonsalves', Firstpost (online, 27 September 2017) $<$ https://www.firstpost.com/india/deporting-rohingyas-would-have-huge-implications-onindia-says-lawyer-colin-gonsalves-4085149.html>.

17 See Ali Johar in Institute on Statelessness and Inclusion, 'Webinar: Human Rights and Covid19. What Now for the Rohingya?' (YouTube, 29 June 2020) 0:16:37-0:24:32 $<$ https://www.youtube.com/watch?v=sPrQEMgK_Bw\&t=35s>.

18 Interview with Anonymous Rohingya Based in India (Tejal Khanna, 2020).

19 'Make Public Evidences of Links of Rohingyas with Islamic State, Pakistan: Congress to Centre', Firstpost (online, 21 September 2017) <https:/www.firstpost.com/politics/makepublic-evidences-of-links-of-rohingyas-with-islamic-state-pakistan-congress-to-centre4068379.html>. Also see Niranjan Sahoo, 'India's Rohingya Realpolitik', Carnegie (online, 31 October 2017) <https://carnegieendowment.org/2017/10/31/india-s-rohingya-realpolitikpub-74590>.

20 See 'Refugees Twice Over: Why Rohingya Who Had Found Shelter in Jammu are Fleeing Again', Scroll.in (online, 7 Feb 2019) < https://scroll.in/article/912146/refugees-twice-overwhy-rohingya-who-had-found-shelter-in-jammu-are-fleeing-again>; Mudasir Amin, Nobody's Children, Owners of Nothing': Analysing the Indian State's Policy Response to the Rohingya Refugee Crisis (Report, The Hindu Centre for Politics and Public Policy 29 August 2018) <https:/www.thehinducentre.com/publications/policyreport/article24828825.ece/BINARY/Policy\%20Report\%20No.24> 81-94. 
(Amendment) Act, 2019 ('CAA'). ${ }^{21}$ According to this Act, people belonging to Hindu, Sikh, Buddhist, Jain, Parsi or Christian communities from Afghanistan, Bangladesh or Pakistan can apply for Indian citizenship. However, this news report has been dismissed as 'fake' by a few Rohingya activists. Sabber Kyaw Min, founder of Rohingya Human Rights Initiative, a Rohingya led nongovernmental organisation based in New Delhi, asserted in a statement on Facebook:

Rohingyas have nothing to do with $C A A$. Yes, there are 31 Rohingya families living in India who are Christians. This amounts to 180 individuals approximately. Rohingyas converted to Christianity in the years, 2002 and 2008. The majority of around 3000 Christian Rohingyas reside in Bangladesh and Burma. Hence, these rumours of Rohingyas converting to Christianity must be stopped by the media as this can cause harm to the image of the community. ${ }^{22}$

The $C A A$ is itself seen as controversial, opposing the secular fabric of the Constitution of India 1950 by granting citizenship on the basis of religion. Even if the Rohingyas were to convert to Christianity to seek citizenship under this Act, they would have to show the state of origin as Bangladesh and not Myanmar. However, it is doubtful that even then their application would be accepted. This is because the Indian government has officially labelled Rohingyas as 'illegal immigrants' who have not only infiltrated from the Rakhine state of Myanmar, but are also a burden to the state's resources and infringe on the rights of Indian citizens. $^{23}$

Rohingyas continue to face religious discrimination and, thus, are not being accommodated as refugees within India. Their harsh treatment does not seem surprising because anti-Muslim violence, in general, has been growing in India. The violence reached its peak when communal riots broke out in the national capital earlier this year. It was also reported that the Delhi police itself was an accomplice in the use of force against Muslims who were peacefully protesting against the exclusionary faith-based citizenship law in February 2020.24

\section{Treating Root CAuses to Stop the Stateless From COMMITTING}

\section{CRIMES}

After surveying the context in which Rohingyas have committed the crime of fraudulently acquiring Indian identity documents, it becomes important to address the root cause of their lack of citizenship status. If such crimes have to be stopped, it is necessary that the Rohingyas living in India acquire citizenship rights through naturalisation where they satisfy the required conditions. This may require a

21 Citizenship (Amendment) Act, 2019, Law No 27 of 2019 (India); 'Muslim, Rohingya Refugees Convert to Christianity to Take Benefit of the Citizenship (Amendment) Act', The Economic Times (online, 24 July 2020) <https://economictimes.indiatimes.com/news/politics-andnation/muslim-refugees-become-christians-to-take-caa-benefit/articleshow/77117484.cms>.

Rohingya Human Rights Initiative, 'Stop False Rumors against Rohingya' (Facebook, 23 July 2020) 0:43:00-1:42:00 $<$ https://www.facebook.com/rohringya/videos/310269613360033/?vh=e\&d=n $>\quad$ (authors translation).

23 Advisory No 24013/29/Misc./2017-CSR.III(i) (n 12).

24 See Six Months Since Delhi Riots, Delhi Police Continue to Enjoy Impunity Despite Evidence of Human Rights Violations, (Report, Amnesty International 28 August 2020) $<$ https://amnesty.org.in/wp-content/uploads/2020/08/Final-Delhi-Report_AmnestyInternational-India-2.pdf $>$. 
drastic shift in the stance of a government that is currently only seeing Rohingyas as illegal immigrants and not even as refugees. Nevertheless, a starting point could be to give Indian citizenship to the children born to Rohingya parents on Indian soil. India may not have signed the 1951 Convention Relating to the Status of Refugees, ${ }^{25}$ nor the 1954 Convention Relating to the Status of Stateless Persons, ${ }^{26}$ but it has signed the Convention on the Rights of the Child ('CRC'). By that measure India, as a state party, must fulfill its obligations under art 7 of the $C R C$ :

1. The child shall be registered immediately after birth and shall have the right from birth to a name, the right to acquire a nationality and, as far as possible, the right to know and be cared for by his or her parents.

2. States Parties shall ensure the implementation of these rights in accordance with their national law and their obligations under the relevant international instruments in this field, in particular where the child would otherwise be stateless. ${ }^{27}$

Moreover, it is the duty of the state to respect international law and treaties, a feature embedded within the Constitution of India 1950 itself. ${ }^{28}$

Hannah Arendt in her work, The Origins of Totalitarianism, ${ }^{29}$ explained the motivation of stateless persons who have to commit crimes and transgress the law in the following manner: 'Since he was the anomaly for whom the general law did not provide, it was better for him to become an anomaly for which it did provide, that of the criminal' ${ }^{30}$ Here, Arendt spoke in the context of stateless people who committed petty crimes like theft in the hope that, after becoming a criminal, they could be recognised by law and receive legal aid. But in a developing country like India, even Indian citizens find it difficult to get legal aid. ${ }^{31}$ It is this harsh reality that pushes the stateless Rohingyas, who live under a constant fear of deportation and who possess no right to legal residence and livelihood opportunities, to commit serious crimes like procuring an Indian passport fraudulently. Nevertheless, this does not absolve sovereign states of their responsibility to provide the right to nationality to the stateless. It is the sovereign act of withholding and arbitrarily denying the right to nationality that abets stateless persons to commit crimes against sovereign states.

25 Convention Relating to the Status of Refugees, opened for signature 28 July 1951, 189 UNTS 150 (entered into force 22 April 1954).

26 Convention Relating to the Status of Stateless Persons, opened for signature 28 September 1954, 360 UNTS 117 (entered into force 6 June 1960).

27 Convention on the Rights of the Child, opened for signature 28 November 1989, (entered into force 2 September 1990).

28 According to Constitution of India 1950 art 51(c), the state shall endeavour to foster respect for international law and treaty obligations in the dealings of organised peoples with one another.

29 Hannah Arendt, The Origins of Totalitarianism (World Publishing Company 1958).

30 ibid 286.

31 See India Justice Report: Ranking States on Police, Judiciary, Prisons and Legal Aid (Report, Tata Trusts October 2019) <https://www.tatatrusts.org/upload/pdf/overall-report-single.pdf>. 